\title{
Improved capital budgeting decision making: evidence from Canada
}

\author{
Abstract \\ Purpose - To evaluate current techniques in capital budget decision making in Canada, \\ including real options, and to integrate the results with similar previous studies. \\ Method - A mail survey of 88 large firms in Canada. \\ Findings - Trends towards sophisticated techniques have continued, however, even in \\ large firms, 17 percent did not use discounted cash flow (DCF). Of those who did, the \\ majority favoured net present value (NPV) and internal rate of return (IRR). Overall \\ between one in ten to one in three were not correctly applying certain aspects of DCF. \\ Only 8 percent used real options.
}

Limitations - One limitation is that the survey does not indicate why managers continue using less advanced capital budgeting decision techniques. A second is that choice of population may bias results to large firms in Canada.

Practical implications - The main area for management focus is real options. Other areas for improvement are administrative procedures, using the weighted average cost of capital (WACC), adjusting the WACC for different projects or divisions, employing target or market values for weights, and not including interest expenses in project cash flows. A small proportion of managers also need to start using DCF.

Originality/value - The evaluation shows there still remains a theory-practice gap in the detailed elements of DCF capital budgeting decision techniques, and in real options. Further, it is valuable to take stock of a concept that has been developed over a number of years. What this paper offers is a fine-grained analysis of investment decision making, a synthesis and integration of several studies on DCF where new comparisons are made, advice to managers and thus opportunities to improve investment decision making. 
Key words capital budgeting, discounted cash flow, real options, investment decision making

\section{Classification research paper}




\section{Improved capital budgeting decision making: evidence from Canada}

\section{Introduction}

Sound financial management and capital investment decision making are critical to survival and long-term success for firms. The global financial crisis has only affirmed this truth. This paper contributes to understanding the role of accounting in business decisions by demonstrating the need for more sophistication in firms' analysis of investment choices, and provides sound advice for practitioners, in order that incorrect decision making and underinvestment can be minimised. This research investigated current capital budgeting practices of large firms in Canada, which appears to have received relatively less attention in the literature than other countries in recent times regarding use of DCF.

DCF has become the dominant evaluation method in Canada (Jog and Srivastava, 1995; Payne et al., 1999), the UK (Arnold and Hatzopoulos, 2000) and the US (Farragher et al., 1999; Graham and Harvey, 2001; Ryan and Ryan, 2002). There has been a resurgence of interest in this field due to concern with the technical aspects of DCF (Bosch et al., 2007; Cary, 2008; Magni, 2009) and inquiry into qualitative techniques (Pike, 2005). However, it isn't always applied correctly and there are pitfalls in its casual use (Drury and Tayles, 1997). The DCF method is the preeminent decision tool available and managers should learn to use it well (Bierman and Smidt, 1993). Misuse is perhaps not surprising given the complexity of current academic debate about what constitutes the correct technique (eg Bosch et al., 2007; Cary, 2008; Magni, 2009). As this paper and previous research show, 
advanced techniques may be well accepted and understood in the scholarly literature but are not universally observed in management practice.

This paper first reviews the concept of DCF, compares the popularity and prevalence of NPV versus IRR, synthesises previous research to illustrate trends, details the 'nitty gritty' of DCF from the practitioner literature and previous research, shows common pitfalls, and then explains how each of the above manifest in a current study of large firms in Canada. The paper partially fills a gap in recent empirical research in that country on capital budgeting practices and DCF techniques, in this decade.

\section{Capital budgeting decision making}

Capital budgeting is the process of analysing investment opportunities in long-term assets which are expected to produce benefits for more than one year (Peterson and Fabozzi, 2002). A central feature of any investment analysis is DCF, which takes into consideration the time value of money, is regarded as theoretically correct, and includes at least four different discounting models: NPV, IRR, modified internal rate of return (MIRR), and profitability index (PI) (Brigham and Ehrhardt, 2002).

Both NPV and IRR are consistent with the goal of maximising a firm's value, use cash flows and consider cash flow timing. With NPV, the present value of future cash flows is generated and when compared with initial outflows, an investment project is seen as acceptable whenever a positive NPV is the outcome. IRR is a percentage rate that equates the present value of future cash inflows with the present value of its investment outlay. 
Finance theory asserts that NPV is the best method for evaluating capital investment projects. In a normal project, cash outflows are followed by annual cash inflows and under these circumstances, NPV and IRR lead to the same investment decisions. Problems with the IRR technique occur in two cases and may lead to incorrect capital budgeting decisions. When project cash flows are abnormal this may lead to multiple IRR calculations, affecting both independent and mutually exclusive projects. When investment projects are mutually exclusive, scale and time differences may lead to incorrect investment decisions and this is a problem associated with the reinvestment rate assumption (Brigham and Ehrhardt, 2002).

\subsection{Trends in capital budgeting decision techniques}

Several studies have dealt with capital budgeting practices of firms in Canada over the past fifty years (see Table 1). More than a decade has passed since the most recent study. In other words there is a long gap from the last study in 1999 to the present, and it is the intent of this research to partially fill the gap. More current studies exist for Australia, the UK and US (Arnold and Hatzopoulos, 2000; Burns and Walker, 1997; Farragher et al., 1999; Graham and Harvey, 2001; Ryan and Ryan, 2002; Truong et al., 2008). The deficiency in the literature is a Canadian phenomenon and the present study is partially justified on the basis that investigation has continued in other countries.

Pike (1996) cautioned about survey comparison which might be problematic due to differences in the method. Nevertheless, given the rarity of longitudinal studies, such comparison is helpful in gleaning some idea about DCF trends in the past 50 years. Eight 
pre-2000 studies in Canada are synthesised in Table 1, which reports overall DCF use, and specifically NPV and IRR. Capital budgeting in Canada was well researched from 1966 to 1995 but following that the literature appears to be silent. In contrast, more recent studies (post 1999) address the US, UK and Australia (see Table 4). For Canada, DCF use appears to have increased from a low of around 35 percent in the early 1960s to 90 percent or more in the early 1990s. Taking all the countries and results together it is clear that DCF is entrenched in the firms covered by extant studies. There appeared to be a lower percentage of firms using NPV and more using IRR in Canada. In the other countries, in later years, there appeared to be an overall higher prevalence of both NPV and IRR. A final point to note from Table 1 is the relatively small questionnaire sample sizes ranging from 58 to 208 firms, and variable response rates from 11 to 58 percent (although the latter only sampled 100 firms). 
Table 1 Chronological and methodological synthesis of capital budgeting studies in Canada

\begin{tabular}{|c|c|c|c|c|c|c|}
\hline Authors & $\begin{array}{l}\text { Year } \\
\text { published }\end{array}$ & $\begin{array}{l}\text { Study } \\
\text { year }\end{array}$ & Sampling frame & Method & $\begin{array}{l}\text { Number of } \\
\text { firms }\end{array}$ & $\begin{array}{l}\text { Number of } \\
\text { respondents } \\
\text { (response rate) }\end{array}$ \\
\hline Nicholson and Ffolliott & 1966 & $\mathrm{n} / \mathrm{a}$ & $\begin{array}{l}\text { Canadian corporations (source of listing } \\
\text { unknown) }\end{array}$ & Questionnaire & 294 & $105(35.7 \%)$ \\
\hline Hoskins and Dunn & 1974 & 1973 & $\begin{array}{l}\text { Canada’s Top } 100 \text { Firms (Financial } \\
\text { Post) }\end{array}$ & $\begin{array}{l}\text { Questionnaire } \\
\text { (12 } \\
\text { interviews) }\end{array}$ & 100 & $58(58 \%)$ \\
\hline Baumgartner and Irvine & 1977 & $\mathrm{n} / \mathrm{a}$ & $\begin{array}{l}1975 \text { CAN-FIL and Scott's Industrial } \\
\text { Directories for Quebec, Ontario and } \\
\text { West Provinces }\end{array}$ & $\begin{array}{l}\text { Questionnaire } \\
\text { (3 case } \\
\text { studies) }\end{array}$ & 400 & $99(24.8 \%)$ \\
\hline Blazouske et al. & 1988 & 1985 & 1985 Financial Post 500 Industrials list & Questionnaire & 500 & $208(41.6 \%)$ \\
\hline Roubi et al. & 1991 & $\mathrm{n} / \mathrm{a}$ & $\begin{array}{l}1989 \text { Financial Post Top } 500 \text { Canadian } \\
\text { corporations }\end{array}$ & Questionnaire & 500 & $80(16 \%)$ \\
\hline
\end{tabular}


Jog and Srivastava

1995

Szpiro and Dimnik

1996

$\mathrm{n} / \mathrm{a}$

Scott’s 1990 Directory of Ontario

Interviews

300

23

Manufacturers

Payne et al.
1994
Standard and Poors Compustat

Questionnaire

588 


\subsection{Non-DCF techniques}

A number of investment analysis methods do not involve discounting cash flows. The most common of these are the payback period (PP) and accounting rate of return (ARR). (Ross et al., 2002; Ross, 2007). Studies in the past 50 years show the increase in DCF has come at the expense of naïve methods, particularly the ARR (see Table 2). 
Table 2 Non-DCF Use among Canadian firms and gaps in subsequent literature

\begin{tabular}{|c|c|c|c|c|c|c|c|}
\hline Authors & $\begin{array}{l}\text { Year } \\
\text { published }\end{array}$ & $\begin{array}{l}\text { Survey } \\
\text { year }\end{array}$ & $\begin{array}{l}\text { Retrospective } \\
\text { year }\end{array}$ & $\begin{array}{l}\text { Most } \\
\text { favoured }\end{array}$ & Least favoured & $\begin{array}{l}\text { Accounting rate } \\
\text { of return } \\
\%\end{array}$ & $\begin{array}{l}\text { Payback period } \\
\%\end{array}$ \\
\hline $\begin{array}{l}\text { Nicholson and Ffolliott } \\
\text { (a) }\end{array}$ & 1966 & $\mathrm{n} / \mathrm{a}$ & & ARR & NPV & 60.8 & 51.5 \\
\hline \multirow[t]{2}{*}{ Hoskins and Dunn ${ }^{(b)}$} & 1974 & 1973 & & $\begin{array}{l}\text { Payback } \\
\text { period }\end{array}$ & PI & & \\
\hline & & & $\begin{array}{l}1962 \\
1967 \\
1972\end{array}$ & & & $\begin{array}{l}27 \\
33 \\
38\end{array}$ & $\begin{array}{l}79 \\
80 \\
79\end{array}$ \\
\hline \multirow[t]{2}{*}{ Blazouske et al. (c) } & 1988 & 1985 & & $\begin{array}{l}\text { IRR } \\
\text { (primary) }\end{array}$ & ARR (primary) & & \\
\hline & & & $\begin{array}{l}1980 \\
1985\end{array}$ & & & $\begin{array}{l}11 \\
9\end{array}$ & $\begin{array}{l}25 \\
19\end{array}$ \\
\hline
\end{tabular}




\begin{tabular}{|c|c|c|c|c|c|c|}
\hline \multirow[t]{3}{*}{ Jog and Srivastava ${ }^{(d)}$} & 1995 & 1991 & $\mathrm{~PB}^{(\mathrm{a})}$ & $\mathrm{ARR}^{(\mathrm{a})}$ & $14.9^{(\mathrm{f})}$ & $53.7^{(\mathrm{t})}$ \\
\hline & & & $\operatorname{IRR}^{(\mathrm{b})}$ & $\mathrm{ARR}^{(\mathrm{b})}$ & $17.5^{(\mathrm{g})}$ & $52.4^{(\mathrm{g})}$ \\
\hline & & & $\operatorname{IRR}^{(\mathrm{c})}$ & $\mathrm{ARR}^{(\mathrm{c})}$ & $19.9^{(h)}$ & $50.0^{(\mathrm{h})}$ \\
\hline Payne et al. ${ }^{\text {(e) }}$ & 1999 & 1994 & NPV & MIRR & 3.37 & 2.42 \\
\hline
\end{tabular}

(a) Percentage using NPV or IRR as primary or secondary method. (b) Respondents were asked to recall techniques used in the past (1962 and 1967). (c) Percentage using NPV or IRR as primary or secondary method. Respondents were asked to recall techniques used in 1980. (d) Percentage using ARR or PB for (f) Replacement projects; (g) Expansion - existing operations; (h) Expansion - new operations. (e) Average ranking regarding the importance of capital budgeting techniques. 


\section{Proper use of and pitfalls in DCF}

Adopting DCF, and NPV in particular, is only the first step towards effective capital budgeting. It is critical to ensure that DCF techniques are properly utilised. In the UK and US this is not necessarily the case and many DCF parameters are treated inconsistently (Booth, 1999; Boquist et al.; 1998; Tyrrall, 1998). DCF techniques deficiencies were considered to be in the application rather than theory. As Drury and Tayles (1997: 86) noted:

despite the increased usage of the more theoretically sound discounting techniques, several writers in both the UK and US have claimed that companies are under investing because they misapply or misinterpret DCF techniques. The following sections review misinterpretation and misapplication.

\subsection{Cash flow estimation}

In terms of specific aspects of correct practice, DCF techniques should be based on cash flows not accounting income (Brealey and Myers, 2003). Canadian firms did not properly determine cash flows in their capital investment analysis. Aspect misapplied were: deducting non-cash expense such as depreciation from accounting income, deducting an allocation of existing overhead costs, subtracting interest expenses and not deducting income tax (Nicholson and Ffolliott, 1966). Treatment of interest expense and other financial costs is one of the most common causes of error in estimating cash flows (Bierman and Smidt, 1993). Including interest charges in the forecasted cash flows as well as in cost of capital double counts the cost of debt and may result in rejecting valuable 
investment projects. Thus, interest expenses and other financing costs should never be included in project cash flows (Bierman and Smidt, 1993).

Firms are expected to recognise inflation in capital budgeting decisions (Brigham and Ehrhardt, 2002). Omitting inflation understates cash inflows and the resulting NPV particularly in long term investment projects. There are two approaches to adjust for inflation: either real cash flows are discounted at a real rate or nominal cash flows discounted at a nominal rate. In one UK study, inflation was properly treated in DCF analysis by only 27 percent of firms (Drury and Tayles, 1997).

\subsection{Discount rate}

The cost of capital is a key parameter of DCF calculation. Firms are expected to use the weighted average cost of funds from various sources including debt, preferred stock and common equity (Brigham and Ehrhardt, 2002). Firms that employ a single cost of funds (for example, the cost of debt if the project is financed by borrowings) make an erroneous choice. The weights used in calculating the cost of capital should preferably be based on the firm's capital structure target or market values, rather than book values. Target values are the ideal, but market values are a good proxy for target values (Brigham and Ehrhardt, 2002). Two studies from Table1 examined whether firms determined the WACC, with 56.9 percent using it one study (Jog and Srivastava, 1995) and similar results (46.2 percent) in the second (Payne et al., 1999). Both studies also revealed that a large number of firms employed theoretically incorrect methods (such as the cost of debt or past 
experience) to determine the discount rate. In Canada, research inquiring about the weights used in computing the WACC is absent.

\subsection{Multiple discount rates and risk}

Using a single WACC for all investment proposals is not advisable. The WACC is the required rate of return on any investment proposals that carry the same level of risk as the firm's existing assets. It should be adjusted up or down, depending on the type of project (for example, replacement projects are lower risk, whereas expansion or new ones are higher risk) or for different organisational units of the firm. There are two recommended methods to adjust the WACC: the pure play and the subjective approach (Ross et al., 2005). The pure play consists of finding firms operating in a similar line of business to the investment project or the division. By looking at the market's required returns, the firm could develop the WACC for a division or new investment opportunity outside the firm's existing business. In cases where pure play cannot be used, management must rely on judgment. This more subjective approach consists of classifying investment projects into risk groups. High-risk projects entail an upward adjusted WACC, while low-risk investments involve downward adjustment. Varying the WACC for risk is not an easy task. Large firms in Canada and the US are cognizant of this difficulty and many are working on developing separate divisional costs of capital (Ross et al., 2005). 


\subsection{Risk analysis methods}

Effective capital investment decisions require not only the use of DCF techniques, proper cash flows, and discount rate estimates, but also risk analysis (Brigham and Ehrhardt, 2002). Uncertainty affects all the parameters required in computing NPV as part of the evaluation phase: the project's life, initial capital expenditure, cash flow estimates and the discount rate. There are many methods available to assist finance managers in handling risk (Ho and Pike, 1991). Simple techniques include adjusting the discount rates and the payback period. Sophisticated methods consist of probabilistic risk analysis such as sensitivity analysis, decision-tree analysis and Monte Carlo simulation. Previous studies (cited in Table 1) suggested that more Canadian firms increasingly used sophisticated techniques when dealing with risk. In the early 1990s, the most popular method was sensitivity analysis.

\subsection{Emerging approaches - real options}

One of the main developments in the capital budgeting literature over the last decade has been real options. Most capital investment projects have options (for example, option to expand or to abandon) that have value (Ross et al., 2005). Conventional DCF analysis should be complemented by real options analysis in order to determine the true NPV (Amram and Howe, 2002). However, NPV is often calculated without identifying and considering real options (Phelan, 1997). Previous empirical literature found that a relatively small number of firms employed real options (Block, 2007; Brounen et al., 
2004; Graham and Harvey, 2001; Ryan and Ryan, 2002). In Canada, there appears to be a complete absence of research regarding their use. As Jog and Srivastava (1995: 37) noted:

One of the growth areas in capital budgeting, the evaluation of real options, is not included in this survey ... As pointed out by one of the anonymous reviewers, this paper may have benefited greatly from an inquiry into this area. However, given of the difficulties of re-doing the survey, we will have to defer discussion on this for a future piece of work.

The present study is such a future piece of work.

\subsection{Administrative procedures}

As well as using correct financial techniques, the literature provides various recommendations about administration and other support for capital budgeting decisions. Preferably, there should be a capital investment manual (Pike, 1988), full-time capital budgeting staff (Klammer and Walker, 1984; Pike, 1989), use of standard model for deriving the NPV or IRR (for example a Microsoft Excel model), supportive information systems (Ho and Pike, 1996) and post-investment audits (Klammer and Walker, 1984; Pike, 1996).

\section{Method}

The method consisted of a mail survey in Canada. The population included the 500 firms listed in the Financial Post (FP500) magazine. This population was chosen for the 
convenience of access to the listing and on the assumption that it would be an accurate representation of the largest firms in Canada. Larger firms are more inclined to use DCF techniques and sophisticated capital budgeting methods, hence classifying the original population as large firms. Small businesses tend to use naïve methods rather than the ones prescribed by financial theory (Block, 1997; Danielson and Scott, 2006), hence the focus on large firms. Also, it is argued that selecting the population as large firms with a similar sampling frame to previous studies facilitated comparison with these studies.

The research instrument consisted of a survey questionnaire (See Appendix 1). Minor problems with language and interpretation in some questions were addressed in the pretest. The survey was mailed to each CFO, addressing firm and respondent demographics and various aspects of capital budgeting. The effective population was 478 since 22 firms from the FP500 could not be reached. That is, it was assumed that firms that could not be reached were no longer part of the population, so the effective population was defined as all those contactable firms in the FP500. The results are based on responses from 88 firms, with a response rate of 18.4 percent. Considering that the survey was addressed to time-constrained CFOs, as well as the commercial sensitivity of some of the requested information, the number of respondents and the response rate are higher than two previous studies using a similar method (Payne et al., 1999) and lower than other, generally earlier, ones (Baumgartner and Irvine, 1977; Blazouske et al, 1988; Jog and Srivastava, 1995; Hoskins and Dunn, 1974; Nicholson and Ffolliott, 1966). Due to confidentiality and other limitations of the method it was not possible to test for nonresponse bias and therefore to establish whether the sample is representative of the population. 
Respondent demographics are shown in Table 3. Based on the characteristics of the largest categories, a picture emerged of CFOs aged in their forties, with a Masters degree (typically an MBA) who had been in their current position for less than four years.

Table 3 Respondent and firm demographics ${ }^{\text {a }}$

\begin{tabular}{lcc}
\hline Position & $\mathbf{n}$ & $\mathbf{\%}$ \\
\hline Chief Financial Officer & 38 & 60.3 \\
Director/Manager - Finance/Treasury/M\&A/Accounting & 13 & 20.6 \\
Senior/VP - Finance/Administration/ Planning/Treasury & 6 & 9.5 \\
Consultant/Specialist/Advisor & 4 & 6.3 \\
Chief Accountant - Capital Projects & 1 & 1.6 \\
Division Controller & 1 & 1.6 \\
& & \\
Age & & \\
$<40$ & & 7.4 \\
$40-49$ & 5 & 47.1 \\
$50-59$ & 32 & 38.2 \\
\hline
\end{tabular}

\section{Tenure}

$<4$ years 


\section{Education}

Undergraduate

25

40.3

Masters

31

50.0

$>$ masters degree

6

9.7

\section{Industry}

Manufacturing

25

36.8

Finance

11

16.2

Energy

9

13.2

Retail

8

11.8

Transportation

7

10.3

Utilities

4

5.9

Technology

3

4.4

Healthcare

1

1.5

\section{Sales revenue (million)}

Under 500

$\$ 500$ - \$999

$\$ 1,000$ - \$1,999

$\$ 2,000-\$ 2,999$

$\$ 3,000-\$ 3,999$

$\$ 4,000-\$ 5,999$

$\$ 6,000$ - \$9,999
6

10

18

9

5

9

4
9.0

14.9

26.9

13.4

7.5

13.4

6.0 
$\$ 10,000$ - \$14,999

$\$ 15,000$ - \$24,999

25 billion and over

\section{Employees}

Under 1,000

$1,000-2,499$

$2,500-4,999$

5,000-9999

$10,000-14,999$

15,000 - 19,999

$20,000-29,999$

30,000 and over
2

3

4.5

1

1.5

3.0

(1)

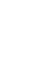


using NPV and 87.7 percent IRR. This slight preference for NPV over IRR confirms previous results in Australia (Truong et al., 2008), the US (Ryan and Ryan, 2002) and UK (Arnold and Hatzopoulos, 2000). Interestingly, a large percentage (78.5) still used the non-DCF payback period.

NPV is now widely utilised among Canadian corporations but a sizeable percentage use IRR as their primary model in capital decision making. Despite the drawbacks of IRR, it seems that managers find it naturally attractive because it appraises investment value in percentage terms which can be easily compared across capital budgeting projects (Cheng, 1994). Other discounting tools such as PI and MIRR were employed less frequently. MIRR was the least prevalent discounting technique, despite its theoretical superiority compared to IRR, and the availability of MIRR functions in popular spreadsheet software. The results also indicated that firms still relied on simple capital budgeting decision techniques such as the payback period and the ARR. This may reflect the need to investigate one of the numerous aspects of capital investment evaluation (Pike, 1996). Indeed, the different financial appraisal tools provide a variety of pertinent information for managerial decision making. For example, the payback period offers a rough gauge of both the risk and liquidity of a capital investment project (Brigham and Ehrhardt, 2002; Peterson and Fabozzi, 2002; Sangster, 1993).

The theory-practice gap is a recurrent theme in the capital budgeting literature, in particular with regard to NPV. Compared to previous Canadian studies, there has been a narrowing of the theory-practice gap (see Table 4). Possible explanations for more widespread use of DCF are the availability of computer software which greatly facilitates 
computations (Pike, 1996; Sangster, 1993), and improvement in the formal education level of managers (Burns and Walker, 1997; Pike, 1996; Sangster, 1993). Despite the recommendations of the financial literature on using NPV as the primary technique, this research found that 42.3 percent of firms indicated a preference for IRR as compared to NPV at 57.7 percent. 
Table 4 Extent of use of NPV and IRR across countries and years in different studies

\begin{tabular}{|c|c|c|c|c|c|c|c|}
\hline Authors & $\begin{array}{l}\text { Year } \\
\text { published }\end{array}$ & $\begin{array}{l}\text { Survey } \\
\text { year }\end{array}$ & $\begin{array}{l}\text { Retrospective } \\
\text { year }\end{array}$ & Country & $\begin{array}{l}\text { Using } \\
\text { DCF } \\
(\%)\end{array}$ & $\begin{array}{l}\text { Using IRR } \\
\text { (\%) }\end{array}$ & $\begin{array}{l}\text { Using NPV } \\
\text { (\%) }\end{array}$ \\
\hline Nicholson and & 1966 & $\mathrm{n} / \mathrm{a}$ & & Canada & 40 & 39.25 & 12.4 \\
\hline $\begin{array}{l}\text { Ffolliott }^{(\mathrm{a})} \\
(\mathrm{n}=105) \\
\text { Hoskins and }\end{array}$ & 1974 & 1973 & & Canada & & & \\
\hline \multicolumn{8}{|l|}{ Dunn (b) } \\
\hline \multicolumn{8}{|l|}{$(\mathrm{n}=58)$} \\
\hline & & & 1962 & & 35 & 17 & 33 \\
\hline & & & 1967 & & 65 & 31 & 54 \\
\hline & & & 1972 & & 79 & 47 & 66 \\
\hline Blazouske et al. & 1988 & 1985 & & Canada & & & \\
\hline
\end{tabular}

(c) 
$(n=208)$

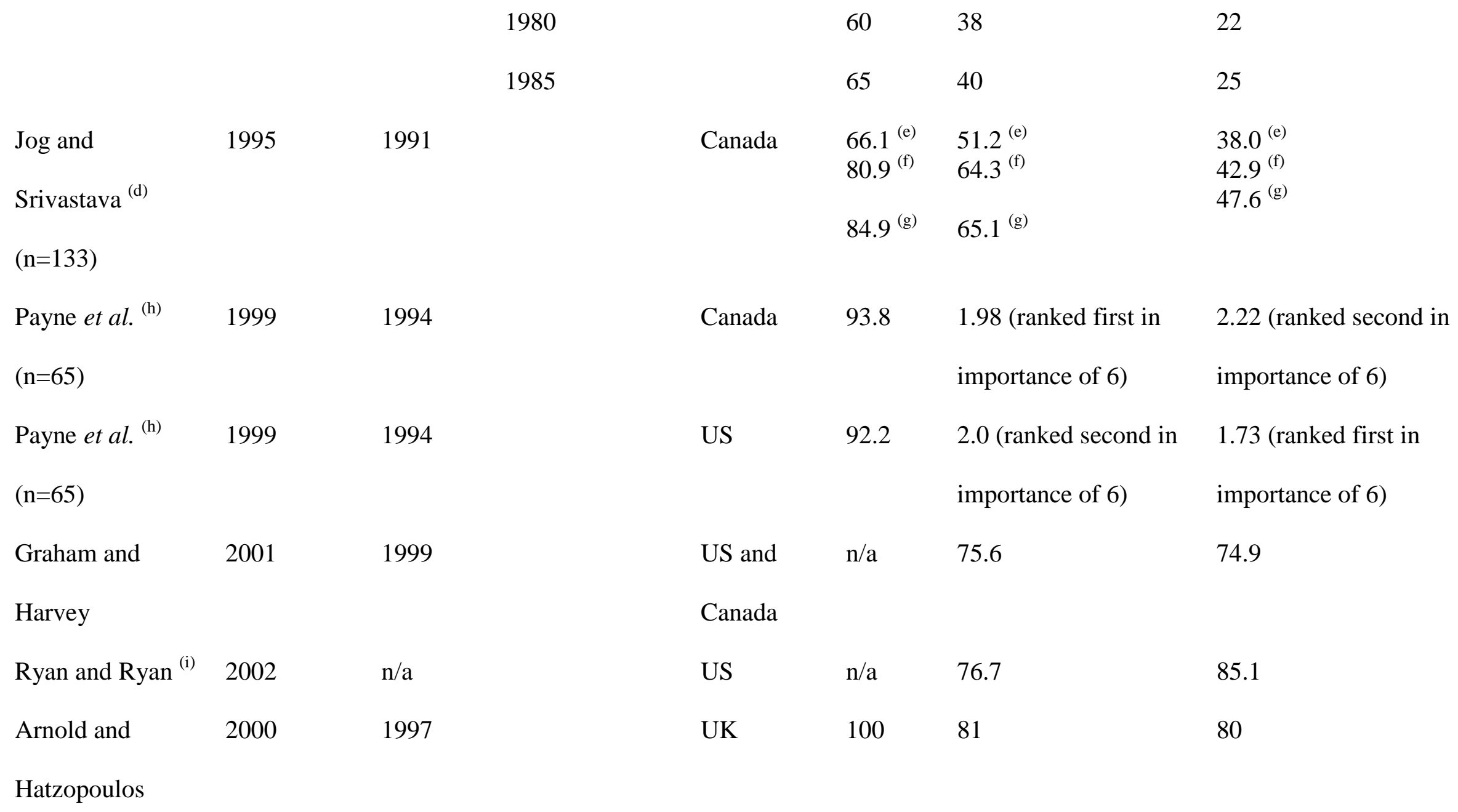


Truong et al.

2008

$(\mathrm{n}=87)$

Current research n/a

$(n=88)$

(a) Percentage using NPV or IRR as primary or secondary method. (b) Respondents were asked to recall techniques used in the past (1962 and 1967). (c) Percentage using NPV or IRR as primary or secondary method. Respondents were asked to recall techniques used in 1980. (d) Percentage using NPV or IRR for (e) Replacement projects; (f) Expansion - existing operations; (g) Expansion - new operations. (h) Average ranking regarding the importance of capital budgeting techniques. (i) Based on the sum of categories labelled 'always' or 'often.' (j) based on the sum of categories labelled always and almost always 
In this research, an overwhelming percentage of firms (91.5 percent) correctly compute NPV or IRR on a cash flow basis rather than accounting income. In Canada, previous empirical evidence about this aspect of capital budgeting is nonexistent. The results are similar to the US study from Farragher et al. (1999) at 85 percent. A large proportion (87.7 percent) dealt with inflation correctly in contrast to previous research by Drury and Tayles (1997). Interest expense and other financial costs were treated properly by the majority (70 percent). In Canada, recent research on treating financing costs in capital budgeting is scarce. Over 76 percent of firms correctly employed the WACC compared to other methods (Table 5), suggesting a reduction in the theory practice gap compared to past studies. Nonetheless, a sizeable number of firms still determined a required rate of return that relied on the cost of a single financing source or an arbitrarily chosen figure. 
Table 5 Details of how DCF is carried out

\begin{tabular}{|c|c|c|c|c|c|c|c|c|c|c|c|c|c|c|}
\hline \multirow[b]{3}{*}{ Authors } & \multirow[b]{3}{*}{$\begin{array}{l}\text { Year } \\
\text { published }\end{array}$} & \multirow[b]{3}{*}{$\begin{array}{l}\text { Survey } \\
\text { year }\end{array}$} & \multirow[b]{3}{*}{$\begin{array}{l}\text { Retrospective } \\
\text { year }\end{array}$} & \multirow[b]{3}{*}{ Country } & \multicolumn{4}{|c|}{$\begin{array}{l}\text { Panel A } \\
\text { Methods for calculating the } \\
\text { discount rate }\end{array}$} & \multicolumn{4}{|c|}{$\begin{array}{l}\text { Panel B } \\
\text { Determining weights in the WACC } \\
\text { and use of multiple discount rates }\end{array}$} & \multicolumn{2}{|c|}{$\begin{array}{l}\text { Panel C } \\
\text { Risk analysis } \\
\text { methods }\end{array}$} \\
\hline & & & & & \multirow[b]{2}{*}{$\begin{array}{l}\text { WACC } \\
(\%)\end{array}$} & \multirow[b]{2}{*}{$\begin{array}{l}\text { Cost } \\
\text { of } \\
\text { debt } \\
(\%)\end{array}$} & \multirow[b]{2}{*}{$\begin{array}{l}\text { Cost } \\
\text { of } \\
\text { equity } \\
(\%)\end{array}$} & \multirow[b]{2}{*}{$\begin{array}{l}\text { Other } \\
(\%)\end{array}$} & \multicolumn{3}{|c|}{$\begin{array}{l}\text { Weights in the WACC } \\
\text { based on }\end{array}$} & \multirow{2}{*}{$\begin{array}{l}\text { Use of } \\
\text { multiple } \\
\text { discount } \\
\text { rates } \\
\end{array}$} & \multirow[t]{2}{*}{$\begin{array}{l}\text { Sensitivity } \\
\text { analysis }\end{array}$} & \multirow{2}{*}{$\begin{array}{l}\text { Risk- } \\
\text { adjusted } \\
\text { discount } \\
\text { rate }\end{array}$} \\
\hline & & & & & & & & & $\begin{array}{l}\text { target } \\
\text { value } \\
(\%)\end{array}$ & $\begin{array}{l}\text { market } \\
\text { value } \\
(\%)\end{array}$ & $\begin{array}{l}\text { book } \\
\text { value } \\
(\%)\end{array}$ & & & \\
\hline $\begin{array}{l}\text { Freeman } \\
\text { and Hobbes } \\
\text { (a) }\end{array}$ & 1991 & 1989 & & Australia & 40 & 39 & 6 & 16 & & & & & & \\
\hline $\begin{array}{l}\text { Jog and } \\
\text { Srivastava }\end{array}$ & 1995 & 1991 & & Canada & 47.2 & 21.9 & 4.1 & 26.8 & & & & & 60 & 31.5 \\
\hline $\begin{array}{l}\text { Payne et al. } \\
\text { (b) }\end{array}$ & 1999 & 1994 & & Canada & 46.2 & 33.9 & 29.2 & $\mathrm{n} / \mathrm{a}$ & & & & & 60 & 49.2 \\
\hline $\begin{array}{l}\text { Arnold and } \\
\text { Hatzopoulos } \\
\text { (a) }\end{array}$ & 2000 & 1997 & & UK & 54 & 11 & 8 & 25 & 30 & 44 & 26 & $\mathrm{n} / \mathrm{a}$ & & \\
\hline $\begin{array}{l}\text { Ryan and } \\
\text { Ryan }\end{array}$ & 2002 & $\mathrm{n} / \mathrm{a}$ & & US & 83.2 & 7.4 & 1.0 & 8.4 & & & & & & \\
\hline Block & 2003 & $\mathrm{n} / \mathrm{a}$ & & US & 85.2 & $\mathrm{n} / \mathrm{a}$ & 6.4 & 8.4 & $\mathrm{n} / \mathrm{a}$ & $\mathrm{n} / \mathrm{a}$ & $\mathrm{n} / \mathrm{a}$ & 46.6 & & \\
\hline Brigham & 1975 & $\mathrm{n} / \mathrm{a}$ & & US & & & & & $\mathrm{n} / \mathrm{a}$ & $\mathrm{n} / \mathrm{a}$ & 93.5 & 52 & & \\
\hline $\begin{array}{l}\text { Gitman and } \\
\text { Mercurio }\end{array}$ & 1982 & 1980 & & US & & & & & 41.8 & 28.8 & 16.4 & $\mathrm{n} / \mathrm{a}$ & & \\
\hline $\begin{array}{l}\text { Gitman and } \\
\text { Vandenberg } \\
\text { (b) }\end{array}$ & 2000 & 1997 & & US & & & & & 49.5 & 34.2 & 19.8 & $\mathrm{n} / \mathrm{a}$ & & \\
\hline $\begin{array}{l}\text { Hoskins and } \\
\text { Dunn }\end{array}$ & 1974 & 1973 & $\begin{array}{l}1962 \\
1967 \\
1972 \\
\end{array}$ & Canada & & & & & & & & & $\begin{array}{l}5 \\
11 \\
31 \\
\end{array}$ & $\begin{array}{l}24 \\
36 \\
38 \\
\end{array}$ \\
\hline $\begin{array}{l}\text { This } \\
\text { research (a) }\end{array}$ & -- & 2007 & & Canada & 76.1 & 9.9 & 1.4 & 12.7 & 50.0 & 20.4 & 29.6 & 63.4 & 92.8 & 76.8 \\
\hline
\end{tabular}


(a) Total percentages do not add up to 100 due to rounding. (b) Percentages do not add up as respondents were allowed more than one answer. 
As shown in Table 5, 29.6 percent of responding firms misapplied that area of capital budgeting analysis by using book value when calculating the WACC. The results are comparable with Gitman and Vandenberg (2000) in the US, and Arnold and Hatzopoulos (2000) in the UK.

Only 63.4 percent of firms used different discount rate across investment projects, which is not consistent with finance theory. In Canada, research into this specific area of capital investments has been lacking. Similarly, research in the US shows there is still a gap.

The majority of Canadian firms use risk analysis tools (see Table 5), with the main ones being sensitivity analysis (92.8 percent), scenario analysis (85.3 percent) and risk-adjusted discount rate (76.8 percent). Compared to past research, this study shows a substantial increase in sensitivity analysis and risk-adjusted discount rate.

Only 4 firms (8.1 percent) used real options when deciding on investment projects. The results confirm Graham and Harvey (2001) and Block (2007) who found a low incidence (11.4 percent and 14.3 percent respectively). In contrast, more recently, Truong et al. (2008) reported that 32 percent of firms in Australia used real options. Failing to consider real options creates a downward bias on the true project value (Phelan, 1997). The results are surprising considering the recent and extensive coverage of real options in the literature. Reasons for not using real options include scepticism, complex and cumbersome techniques, lack of management support, DCF being considered a proven method, and real options too risky (Block, 2007; Cotter et al., 2003). 
In terms of administration and other support, almost 58 percent possessed a capital investment manual, around 52 percent indicated that they had at least one member of their staff assigned full-time to capital budgeting and over two-thirds employed a standard model (example a Microsoft Excel model). Project related financial parameters such as expected cash outflows and inflows were satisfactorily acquired from firms' capital budgeting information systems. Conversely, project expected economic life, macroeconomics (for example the inflation rate), and post-audit review data were less frequently obtained from the information system (fewer than half indicated often or very often available). A majority conduct post-audits of major capital investment projects (84.5 percent), even though suitable data from the information system was not always reported as being available.

\section{Implications for practice}

A theory-practice gap remains in the DCF application among large firms in Canada. Apart from not using DCF, several areas of DCF analysis were misapplied. This study provides those evaluating investment projects as well as those conceiving capital budgeting manuals or policies, knowledge about common pitfalls which, if acted on could improve decision making.

Large firms in Canada should provide training for managers and analysts to ensure capital budgeting tools, in general, and DCF, in particular, are applied in accordance with normative textbook approaches. Areas that need to be emphasised during training and considered in decision making are: (1) DCF, (2) superiority of NPV over IRR, (3) 
multiple discount rates for different projects or divisions with different risk, (4) interest expenses not to be considered in computing expected cash flows, (5) the WACC is the proper discount rate rather than a single source of financing, (6) target or market weights should be employed in calculating the WACC, (7) use real options, (8) provide a policy manual, (9) dedicated staff, (10) standard models, (11) supportive capital budgeting information systems to ensure parameters such as expected economic life and inflation rate are readily available, (12) software products to make the required analysis easier, (13) post-investment audits and (14) training and review for compliance.

\section{Limitations and Further Research}

Several aspects of this research place limitations on the outcomes and may bias the results. First, non-response bias is potentially an issue with surveys. Because confidential information was sought, identifying respondents and firms was avoided in order to maximise response rate. Second, the research was limited to a small sample of Canada's largest firms. Was this sample representative of the population? Are capital budgeting practices generalisable to firms in other geographic areas? Canada could be subject to the influence of the very large neighboring economy in the US and as the comparisons in this paper indicate, our new Canadian figures are not that different from US studies conducted this decade. Nonetheless, research method theory generally cautions about generalising results to any population outside that sampled, and other literature argues about comparing results between different cultures. Third, this study was also limited to large firms because they are most likely to employ capital budgeting procedures based on DCF as well as understand the technicality of these methods. Consequently, the extent to which 
large businesses rigorously and successfully adopt DCF techniques cannot necessarily be generalised to businesses of all sizes. Fourth, the study relied on a traditional survey method. This did have the advantage of facilitating comparison with previous studies that relied on a similar method, but a more novel approach could have been used. Fifth, the focus of this study was on selected aspects of capital budgeting. Successful use of DCF is one of the many decisive factors leading to successful capital investment. Other capital budgeting phases (for example, generating investment ideas) are important. Finally, this study, and much of the capital budgeting literature, assumes that managers make rational decisions, carefully using logical, proven techniques. It may well be that other dynamics are at play. The vast literature on more general managerial decision making demonstrates that this may be the case and that many decisions in a complex, fast paced environment are made on intuitive and pragmatic grounds.

Regarding further research, a fruitful area is an in-depth study of DCF practices by means of case study and interviews, to investigate contextual and organisational elements that may explain why businesses apparently misapply DCF during the appropriation stage. It may well be that attention to the technical correctness of DCF and other capital budgeting techniques takes second place to time demands and other business imperatives. Second, although most finance textbooks advocate real options, very few responding firms actually used them. It would be interesting to follow the progression of real options over the next decade, in the same vein as the surveys reported here on DCF, to identify if this technique gains more recognition in various countries, especially for those firms with large capital budgets. Finally, another area where research is limited is capital budgeting 
practices of small firms. For example, a study similar to that of Block (1997) or Danielson and Scott (2006) in the US could be replicated in Canada.

\section{Conclusion}

This paper examined capital budgeting sophistication with field data from large firms in Canada. The literature review and survey implied improvement over time. Although each study had different characteristics, that is, dissimilar samples, questions asked and response rates, the following broad inferences can be drawn: DCF is the most favored investment decision technique, and, as advocated by the literature, have become standard. In the past five decades, empirical studies dealing with large firms in North America and the UK have proven one point: DCF techniques have become increasingly accepted and are today the dominant methods to evaluate capital investment projects. Non-DCF techniques are still employed, though their use has declined; the WACC was relatively widely used, a majority of large firms in Canada employ sensitivity analysis as the most favored technique for dealing with risk and use of real options is limited. There is recent evidence from both academics and practitioners that DCF techniques are misused in the UK, US and now Canada, which may lead to incorrect investment decisions.

Despite the relatively widespread use of DCF, sophistication in detailed application is moderate to good, suggesting restrained improvement since earlier studies. Although NPV and IRR were the most employed project appraisal techniques, a number of firms favor IRR as compared to NPV. Financial theory advocates using the superior NPV. There were several areas where more emphasis in training and practice could further 
enhance investment decision making. The main area for focus is real options, as this had the lowest prevalence. Other areas where around a third of firms could improve are administrative procedures (standard spreadsheet models, capital investment manual, more extensive details in the information system), using the WACC, adjusting the WACC for different projects or divisions, employing target or market values weights and not including interest expenses in project cash flows. A small proportion of firms also need to start using DCF.

Limitations included being confined to one country and a one-shot survey. Nonetheless, this research adds to the body of knowledge on capital investments in general and DCF in particular, by showing where Canada fits in this decade and identifying specific areas for improvement. This study improves practice by addressing the most common pitfalls encountered by those who use DCF techniques. Even though best practice in DCF is well known in academic literature, in practice it is not uniformly well-utilised. Pike (2005) indicated that capital budgeting has received considerable research attention and is unlikely to turn up surprising new findings, and this has partially proven to be the case here. Nonetheless the room for improvement of large Canadian firms in the current era is notable and raises questions such as why this continues to be the case and why real options are not more widespread.

\section{References}

Amram, M. and Howe, K.M. (2002), “Capturing the value of flexibility”, Strategic Finance, Vol. 84, No. 6, pp. 10-13. 
Arnold, G.C. and Hatzopoulos, P.D. (2000), “The theory-practice gap in capital budgeting: evidence from the United Kingdom”, Journal of Business Finance and Accounting, Vol. 10, No. 5, pp. 603-626.

Baumgartner, H. and Irvine, V.B. (1977), “A survey of capital budgeting techniques used in Canadian companies”, Cost and Management, Vol. 50, No. 1, pp. 51-53.

Bierman, H. and Smidt, S. (1993), The Capital Budgeting Decision: Economic Analysis of Investment Projects, 8th ed., Prentice Hall, Toronto.

Blazouske, J.D., Carlin, I. and Kim, S.H. (1988), “Current capital budgeting practices in Canada”, CMA Magazine, March, pp. 51-54.

Block, S. (1997), “Capital budgeting techniques used by small business firms in the 1990s”, The Engineering Economist, Vol. 42, No. 4, pp. 289-302.

Block, S. (2003), “Divisional cost of capital: a study of its use by major U.S. firms”, The Engineering Economist, Vol. 48, No. 4, pp. 345-362.

Block, S. (2007), “Are real options actually used in the real world?”, The Engineering Economist, Vol. 52, No. 3, pp. 255-267. 
Booth, R. (1999), “Avoiding pitfalls in investment appraisal”, Management Accounting, November, pp. 22-23.

Boquist, J.A., Milbourn, T.T. and Thakor, A.V. (1998), “How do you win the capital allocation game?”, MIT Sloan Management Review, Vol. 39, No. 2, pp. 59-71.

Bosch, M. T., Montllor-Serrats, J. and Tarrazon, M. A. (2007), "NPV as a function of the IRR: the value drivers of investment projects”, Journal of Applied Finance, Vol. 17, No. 2, pp. 41-45.

Brealey, R. and Myers, S. (2003), Principles of Corporate Finance, McGraw-Hill/Irwin, New York.

Brigham, E.F. (1975), “Hurdle rates for screening capital expenditure proposals”, Financial Management, Vol. 4, No. 3, pp. 17-26.

Brigham, E.F. and Ehrhardt, M.C. (2002), Financial Management: Theory and Practice, $10^{\text {th }}$ ed., South-Western, Mason, Ohio.

Brounen, D., De Jong, A. and Koedijk, K. (2004), “Corporate finance in Europe: confronting theory with practice”, Financial Management, Vol. 33, No. 4, pp. 71-101.

Burns, R.M. and Walker, J. (1997), “Capital budgeting among the Fortune 500: a rational approach”, Managerial Finance, Vol. 23, No. 9, pp. 3-15. 
Cary, D. (2008), “An integrated approach to alternative capital budgeting techniques, mutually exclusive projects, and consistency with the net present value rule”, Journal of American Academy of Business, Vol. 13, No. 2, pp. 14-19.

Cheng, A. C.S., Kite D. and Radtke, R. (1994), “The applicability and usage of NPV and IRR capital budgeting techniques”, The Engineering Economist, Vol. 40, No. 7, pp. 1036.

Cotter, J., Marcum, B. and Martin, D. (2003), “A cure for outdated capital budgeting techniques”, Journal of Corporate Finance and Accounting, Vol. 14, No. 3, pp. 71-80.

Danielson, M.G. and Scott, J.A. (2006), “The capital budgeting decisions of the small business”, Journal of Applied Finance, Vol. 16, No. 2, pp. 45-56.

Drury, C. and Tayles, M. (1997), "The misapplication of capital investment techniques”, Management Decision, Vol. 35, No. 2, pp. 86-93.

Farragher, E.J., Kleiman R.T. and Sahu, A.P. (1999), “Current capital investment practices”, The Engineering Economist, Vol. 44, No. 2, pp. 137-150.

Freeman, M. and Hobbes, G. (1991), “Capital budgeting: theory versus practice”, Australian Accountant, Vol. 61, No. 8, pp. 36-41. 
Gitman L.J. and Mercurio, V. (1982), “Cost of capital techniques used by major U.S. firms: survey and analysis of Fortune’s 1000”, Financial Management, Vol. 11, pp. 2129.

Gitman L.J. and Vandenberg, P. (2000), “Cost of capital techniques used by major US firms: 1997 vs. 1980”, Financial Practice and Education, Vol. 10, No. 2, pp. 53-68.

Graham, J. and Harvey, C. (2001), “The theory and practice of corporate finance: evidence from the field”, Journal of Financial Economics, Vol. 60, No. 2-3, pp. 187-243.

Ho, S.S.M. and Pike, R.H. (1991), "Risk analysis in capital budgeting contexts: simple or sophisticated?”, Accounting and Business Research, Vol. 21, No. 83, pp. 227-238.

Ho, S.S.M. and Pike, R.H. (1996), “Computer decision support for capital budgeting: some empirical findings of practice?”, Journal of Information Technology, Vol. 11, No. 2, pp. 119-128.

Hoskins, C.G. and Dunn, M.J. (1974), “The economic valuation of capital expenditure proposals under uncertainty: the practice of large corporations in Canada”, Journal of Business Administration, Vol. 6, No. 1, pp. 44-55.

Jog, M.J. and Srivastava, A.K. (1995), “Capital budgeting practices in corporate Canada”, Financial Practice and Education, Vol. 5, No. 2, pp. 37-43. 
Klammer, T. and Walker, M.C. (1984), “The continuing increase in the use of sophisticated capital budgeting techniques”, California Management Review, Vol. 27, No. 1, pp. 137-148.

Magni, C.A. (2009), “Correct or incorrect application of CAPM? Correct or incorrect decisions with CAPM?”, European Journal of Operational Research, Vol. 192, No. 2, pp. 549-560.

Nicholson, J.T. and Ffolliott, J.D. (1966), “Investment evaluation criteria of Canadian companies”, The Business Quarterly, Summer, pp. 54-62.

Payne, J.D., Heath, W.C. and Gale, L.R. (1999), “Comparative financial practice in the US and Canada: capital budgeting and risk assessment”, Financial Practice and Education, Vol. 9, No. 10, pp. 16-24.

Peterson, P.P. and Fabozzi, F.J. (2002), Capital Budgeting: Theory and Practice, Wiley and Sons, New York.

Phelan, S.E. (1997), “Exposing the illusion of confidence in financial analysis”, Management Decision, Vol. 35, No. 2, pp. 163-168.

Pike, R.H. (1988), “An empirical study of the adoption of sophisticated capital budgeting practices and decision-making effectiveness”, Accounting and Business Research, Vol. 18, No. 72, pp. 341-51. 
Pike, R.H. (1989), “Do sophisticated approaches improve investment decision-making effectiveness”, The Engineering Economist, Vol. 34, No. 2, pp. 149-161.

Pike, R.H. (1996), “A longitudinal survey on capital budgeting practices”, Journal of Business Finance and Accounting, Vol. 23, No. 1, pp. 79-92.

Pike, R.H. (2005), “Capital investment decision-making: some results from studying entrepreneurial businesses”, Accounting and Business Research, Vol. 35, No. 4, pp. 352353.

Ross, S.A. (2007). Fundamentals of Corporate Finance, $4^{\text {th }}$ Aust ed., McGraw Hill, Sydney.

Ross, S.A., Westerfield, R.W. and Jaffe, J.F. (2002). Corporate Finance, $6^{\text {th }}$ ed., McGraw Hill, New York.

Ross, S.A., Westerfield, R.W., Jordan, B.D. and Roberts, G.S. (2005), Fundamentals of Corporate Finance, $5^{\text {th }}$ Canadian ed., McGraw Hill, Ryerson.

Roubi, R.R., Barth, R.T. and Faseruk, A. (1991), “Capital budgeting use in Canada: sophistication and risk attributes”, Journal of Applied Business Research, Vol. 7, No. 4, pp. 83-89. 
Ryan, P.A. and Ryan, G.P. (2002), “Capital budgeting practices of Fortune 1000: how have things changed?”, Journal of Business and Management, Vol. 8, No. 4, pp. 355-364.

Sangster, A. (1993), “Capital investment appraisal techniques: a survey of current usage”, Journal of Business Finance and Accounting, Vol. 20, No. 3, pp. 307-332.

Szpiro, D. and Dimnik, T. (1996), “Capital budgeting in multinational organizations: exploring the strategic context”, Managerial Finance, Vol. 22, No. 1, pp. 58-74.

Truong, G., Partington, G. and Peat, M. (2008), “Cost-of-capital estimation and capitalbudgeting practice in Australia”, Australian Journal of Management, Vol. 33, No. 1, pp. 95-122.

Tyrrall, D.E. (1998), “Discounted cash flow: rational calculation or psychological crutch?”, Management Accounting, February, pp. 46-48. 


\section{Appendix 1 Survey questionnaire}

1. Please indicate how frequently your company employs the following evaluation techniques when deciding which investment projects to pursue? (Please tick one square per line)

$\begin{array}{llll}\text { Never } & \text { Almost } & \text { Almost } & \text { Always } \\ & \text { never } & \text { always } & \\ & 2 & 3 & 4\end{array}$

Net present value (NPV)

Internal rate of return (IRR)

Modified internal of return (MIRR)

Profitability index

Payback period

Accounting rate of return $(*)$

Real options

Other (Please specify, pp.

$\left(^{*}\right)$ Average earnings return on assets

2. Which of the following techniques does your firm favor when deciding which investment projects to pursue? (Please tick one square only)

$\square$ Net Present Value (NPV)

$\square$ Internal Rate of Return (IRR)

3. When computing the Internal Rate of Return (IRR) or Net Present Value (NPV), does your firm use: (Please tick one square only)

$\square$ Cash flows 
$\square$ Accounting income

4. In computing the Internal Rate of Return (IRR) or Net Present Value (NPV), do you deduct interest and other financing costs from revenue to arrive at cash flows?

$\square$ Yes $\quad \square$ No

5. Which of the following approaches is used in your company to determine the minimum acceptable rate of return (discount rate) to evaluate proposed capital investments? (Please tick one square only)

$\square$ Weighted average cost of capital (WACC)

$\square$ Cost of debt

$\square$ Cost of equity capital

$\square$ An arbitrarily chosen figure is used

$\square$ Another rate (Please specify, pp.

6. If the Weighted Average Cost of Capital (WACC) is used, the weights are defined by: (Please tick one square only)

$\square$ Book values derived from the balance sheet

$\square$ Current market values

$\square$ Target values (long term targets)

7. Do you have different rates of return that are required for different divisions, subsidiaries or projects of the firm?

$\square$ Yes $\quad \square$ No 
8. When your firm uses a method requiring discounted cash flows (for example, NPV or IRR, pp.

Are nominal cash flows discounted at the nominal discount rate? (Or alternatively, are real cash flows $(*)$ discounted at the real discount rate $(* *)$ ?)

$\square$ Yes $\quad \square$ No

(*) Real cash flows = in current terms.

$(* *)$ Real interest rate $=$ Nominal interest rate - Inflation rate.

9. Which technique does your firm use to assess a project's risk? (Please tick one square per line)

$\begin{array}{llll}\text { Never } & \text { Almost } & \text { Almost } & \text { Always } \\ & \text { never } & \text { always } & \\ 1 & 2 & 3 & 4\end{array}$

Scenario analysis (i.e., base case,

worst-case, best-case forecasts)

Sensitivity analysis

Simulation analysis (e.g., Monte Carlo

simulation)

Decision tree analysis

Other (Please specify, pp.

10. Which method does your firm use to incorporate risk in capital budgeting decisions? (Please tick one square per line)

Never Almost Almost Always 
\begin{tabular}{llllll}
\multicolumn{1}{c}{ never } & \multicolumn{2}{l}{ always } \\
1 & 2 & 3 & 4
\end{tabular}

Risk-adjusted discount rate

Certainty equivalent approach $(*)$

Other (Please specify, pp.

(*) Certainty equivalent approach: Every cash inflow that is not known with certainty is scaled down, and the riskier the flow, the lower its certainty equivalent value.

11. Please estimate the average proportion of total capital expenditures your firm made in the last five years that should be classified within these three investment categories:

Replacement Projects:

Expansion Projects - Existing Operations: _ _ _ \%

Expansion Projects - New Operations: _ _ _ $\%$

Total: $\quad 100 \%$

12. Is there at least one member of your staff assigned full-time to capital investment analysis?

$\square$ Yes $\quad \square$ No

13. Does your firm possess a capital investment manual (written capital investment guidelines)?

$\square$ Yes $\quad \square$ No

14. Does your company require the use of standard model (for example, a standard Microsoft

Excel ${ }^{\circledR}$ model) for deriving the Net Present Value (NPV) or Internal Rate of Return (IRR)?

$\square$ Yes $\quad \square$ No 
15. Does your company conduct post-audits of major capital expenditure?

$\square$ Yes $\quad \square$ No

16. Please tick one square in each line indicating the degree of uncertainty or predictability in your company's environment:

\begin{tabular}{|c|c|c|c|c|c|c|}
\hline & Never & & & & & Always \\
\hline & predictable & & & & & predictable \\
\hline & 1 & 2 & 3 & 4 & 5 & 6 \\
\hline Action of suppliers & $\square$ & $\square$ & $\square$ & $\square$ & $\square$ & $\square$ \\
\hline Iction of competitors & $\square$ & $\square$ & $\square$ & $\square$ & $\square$ & $\square$ \\
\hline ustomer preferences and tastes & $\square$ & $\square$ & $\square$ & $\square$ & $\square$ & $\square$ \\
\hline Behavior of financial/capital markets & $\square$ & $\square$ & $\square$ & $\square$ & $\square$ & $\square$ \\
\hline Related governmental regulations & $\square$ & $\square$ & $\square$ & $\square$ & $\square$ & $\square$ \\
\hline Actions of trade unions & $\square$ & $\square$ & $\square$ & $\square$ & $\square$ & $\square$ \\
\hline of related technological changes & $\square$ & $\square$ & $\square$ & $\square$ & $\square$ & $\square$ \\
\hline
\end{tabular}

17. How often is the following investment project-related financial data for capital investment decisions obtained from your company’s capital budgeting information system (*)? Please tick one box in each line.

$\begin{array}{cccccc}\text { Never } & \text { Very } & \text { Little } & \text { Some } & \text { Often } & \text { Very } \\ & \text { little } & & & & \text { often } \\ & & 3 & 4 & 5 & \\ & & & & & 6\end{array}$

Project expected cash outflows 
Project expected cash inflows

Cost of capital and required returns

Project expected economic life

Macroeconomics (e.g., inflation rate)

Post-audit review

(*) Capital budgeting information system is defined as an organised collection, storage, and presentation system of data and other knowledge for capital investment decision making. Example of capital budgeting information system includes executive information systems (EIS), decision support systems (DSS), and spreadsheet software (For example, Excel or Lotus 1-2-3).

A. Demographics

18. Please provide the following demographic information for the study. (Check one square for the items listed below)
a) Age of CFO (years)
b) CFO tenure (time in current
c) CFO education

$\square<40$

job)

$\square$ Undergraduate

4049

$<4$ years

$\square$ MBA degree

5059

49 years

$\square$ non-MBA masters

$\square \geq 60$

$>9$ years

$\square$ > masters degree

19. Your job title?

\section{B. Other information}

20. Tick the square which represents your PREDOMINANT area of activity: 
$\square$ Energy $\square$ Manufacturing $\square$ Finance $\square$ Utilities $\square$ Technology $\square$ Retail $\square$ Healthcare

$\square$ Transportation

21. What is your firm's approximate number of employees?

22. What is your firm's approximate long-term debt to total assets ratio? _ (\%) (For example, $45 \%)$

23. What is your firm's approximate net fixed assets (*) amount? \$

(*) Defined as the value of fixed assets after depreciation

24. What is your firm's approximate sales revenue? \$

25. Please indicate how would your rate your company's performance as compared to firms of similar sales volume in your industry and regions? (Please tick one square per line)

$\begin{array}{lllll} & \text { Much } & \text { Lower } & \text { Greater } & \text { Much } \\ & \text { lower } & & & \text { greater } \\ \text { Sales growth } & 1 & 2 & 3 & 4 \\ \text { After tax return on total assets } & \square & \square & \square & \square \\ \text { Profitability } & \square & \square & \square & \square \\ \text { Overall firm performance } & \square & \square & \square & \square\end{array}$

